\section{Respon Pertumbuhan Jagung (Zea mays) Dengan Pemberian Urea Bersalut Zeolit Sebagai Nitrogen Lepas Lambat}

\author{
Nur Aina \\ Oslan Jumadi \\ St. Fatmah Hiola
}

Abstrak. Penelitian ini merupakan penelitian eksperimen yang bertujuan untuk mengetahui bagaimana respon pertumbuhan jagung (Zea mays) dengan pemberian urea bersalut zeolit sebagai nitrogen lepas lambat, dilaksanakan mulai April sampai Desember 2017. Pembuatan pupuk dilakukan di Laboratorium Mikrobiologi Tanah Lantai III Timur Jurusan Biologi Universitas Negeri Makassar. Penanaman dan pemeliharaan jagung dilakukan di Rumah Kaca Ekofisiologi Balai Penelitian Tanaman Serelia (Balitsereal) Maros dan Analisis data nitrogen di Laboratorium Tanah Balai Pengkajian Teknologi Pertanian (BPTP) Kabupaten. Maros Sulawesi Selatan. Penelitian ini menggunakan Rancangan Acak Kelompok (RAK) 3 pengelompokan dengan perlakuan Kontrol, Urea, Phosfat, Kalium (UPK), UPK Zeolit 10\%, UPK Zeolit 30\%, dan UPK Zeolit 50\%. Varietas jagung yang digunakan adalah HJ 21 Agritan. Parameter pengamatan yakni lingkar batang, kadar klorofil daun, biomassa tanaman (akar, batang dan daun), berat tongkol, panjang tongkol, nitrogen daun dan nitrogen biji. Teknik asalisis data dilakukan dengan menggunakan teknik analisis varian (Uji F) /ANOVA pada taraf kepercayaan $\alpha=0,05 \%$. Kemudian dilanjutkan dengan uji lanjut Duncan yang menggunakan program SPSS statistik 20. Hasil penelitian menujukan bahwa terjadi interaksi antara pupuk urea bersalut zeolit terhadap hasil produksi pada berat tongkol dan panjang tongkol jagung dengan hasil berbeda terhadap perlakuan lainnya. Hasil terbaik pada perlakuan urea bersalut zeolit dengan konsetrasi 10\%. Sedangkan untuk lingkar batang, kadar klorofil daun, biomassa tanaman (akar, batang dan daun), nitrogen daun dan niitrogen biji menunjukkan hasil yang tidak berpengaruh namun jika dilihat hasil rata-rata aplikasi urea bersalut zeolit dengan konsentrasi 30\% paling tinggi.

Kata Kunci: Pertumbuhan jagung, aplikasi urea bersalut zeolit, pupuk lepas lambat

\section{Pendahuluan}

Jagung merupakan salah satu tanaman pangan yang penting karena jagung adalah sumber karbohidrat kedua setelah beras yang dikonsumsi dan sangat disukai masyarakat di Indonoesia. Permintaan terhadap jagung semakin meningkat, selanjutnya mendorong para produsen untuk melakukan perbaikan terhadap sistem budidaya dalam meningkatkan hasil produksinya. Suatu upaya yang dilakukan oleh para petani Indonesia untuk meningkatan produktivitas tanaman jagung ialah dengan pemeliharaan kesuburan tanah. Pemeliharaan kesuburan tanah sebagai aspek budidaya yang tidak pernah lepas dalam kaitannya dengan peningkatan produktivitas tanaman jagung. Tanaman jagung adalah tanaman C4 yang banyak memerlukan unsur hara untuk kelangsungan hidupnya. Unsur hara tersebut terdiri dari C, H, O, N, P, K, Ca, Mg, S, Fe, B, Cu, Zn, Mo, Mn, Cl, Si, Na, dan Co. Umumnya berasal dari pelapukan batuan dalam tanah. Namun, kemampuan tanah dalam menyediakan unsur hara bagi tanaman sangat terbatas karena mikroorganisme yang berperan dalam proses pelapukan

\section{BIONATURE}

ISSN $1411-4720$

Abstract. This study is an experimental research that aims to find out how the response of corn growth (Zea mays) with urea-coated zeolite as nitrogen release slowly, implemented from April to December

2017. The making of fertilizer is done in Biology Laboratory of East III Floor Department of Biology Faculty of Mathematics and Natural Sciences of Makassar State University. The cultivation and maintenance of maize was conducted at Greenhouse of Ecophysiology of Seraca Crops Research Institute (Balitsereal) Maros and Analysis of nitrogen data at Soil

Laboratory of Agricultural Technology Assessment Institute (BPTP) Regency. Maros South Sulawesi. This research used Randomized Block Design (RAK) 3 grouping with Control, Urea, Phosphate, Potassium (UPK), UPK Zeolite 10\%, UPK Zeolit 30\%, and UPK Zeolit $50 \%$. The corn variety used was HJ 21 Agritan. Observation parameters were stem circumference, leaf chlorophyll content, plant biomass (root, stem and leaves), cob weight, ear length, seed weight, leaf nitrogen and seed nitrogen. The technique of data origin is done by using variance analysis technique ( $F$ test) / ANOVA at the level of trust $\alpha=0,05 \%$. Then proceed with Duncan's advanced test using SPSS statistic program 20. The results showed that there was an interaction between zeolite-coated urea fertilizer on the yield of cob and corncob with different results on the other treatment. The best results on urea-coated zeolite treatment with $10 \%$ concentration. While for stem circumference, leaf chlorophyll content, plant biomass (root, stem and leaf), seed weight, leaf nitrogen and seed nitrogen showed no effect but when viewed the average result of urea coated application of zeolite with the highest $30 \%$ concentration.

Keywords: The growth of corn, the application of urea zeolite coated, slow release fertilizersp., Thalassiosira sp., Probiotic Bacteria.

Nur Aina
Universitas Negeri Makassar
Indonesia
Oslan Jumadi
Universitas Negeri Makassar
Indonesia
St. Fatmah Hiola
Universitas Negeri Makassar
Indonesia


berbeda antara jenis dan lapisan tanah satu dengan lainnya. Oleh karena itu, pemupukan merupakan salah satu cara untuk menyediakan unsur hara yang dibutuhkan oleh tanaman (Nasir, M, 2011).

Pemupukan dapat meningkatkan hasil panen jagung baik secara kualitatif maupun kuantitatif. Hal ini disebabkan pemupukan dapat meningkatkan ketersediaan unsur hara, kesehatan tanaman dan menekan perkembangan penyakit. Pupuk yang biasa digunakan untuk tanaman jagung ialah pupuk organik (contohnya pupuk kandang) maupun pupuk anorganik (contohnya pupuk urea dan pupuk NPK). Pupuk urea mengandung unsur nitrogen yang cukup tinggi sekaligus sangat dibutuhkan oleh tanaman. Tanaman memerlukan nitrogen untuk menunjang proses metabolime tubuhnya. Akan tetapi, urea juga merupakan jenis pupuk yang mudah menguap dan mudah tercuci dalam tanah, sehingga memerlukan perlakuan khusus untuk mencegah terjadinya pencucian tersebut (Prahasta, 2009).

Unsur nitrogen ialah faktor yang berpengaruh terhadap hasil jagung manis. Kekurangan nitrogen pada tanaman jagung manis dapat disebabkan oleh beberapa faktor diantaranya ialah sifat dasar dari unsur $\mathrm{N}$ yang mudah hilang dari tanah sehingga pemupukan yang dilakukan tidak dapat dimanfaatkan secara maksimal oleh tanaman jagung. Tingkat kehilangan nitrogen dalam tanah akan semakin cepat, apabila tanah tersebut memiliki daya jerap atau kapasitas tukar kation (KTK) rendah. Beberapa cara dilakukan oleh petani agar tanaman jagung tidak kekurangan unsur $\mathrm{N}$, diantaranya ialah penambahan dosis urea dari dosis anjuran. Namun penggunaan pupuk urea yang berlebihan juga berdampak pada tingginya biaya pemupukan tanaman jagung sehingga menyebabkan kerugian bagi petani karena tidak diimbangi dengan peningkatan produksi tanaman jagung. Untuk itu, dibutuhkan cara untuk meningkatkan daya jerap tanah atau KTK dengan menambah bahan organik dan bahan yang memiliki KTK sangat tinggi diantaranya ialah zeolit yang memiliki sifat sebagai penukar ion yang diharapkan unsur hara yang diberikan melalui pemupukan dapat diikat oleh zeolit yang tidak mudah tercuci didalam tanah sebelum dimanfaatkan tanaman sehingga dapat meningkatkan efisiensi pemupukan (Kusdarto, 2008).

Berdasarkan uraian yang telah dipaparkan maka penelitian ini dilakukan untuk melihat respon pertumbuhan tanaman jagung dengan pemberian urea bersalut zeolit sebagai nitrogen lepas lambat.

\section{Rumusan Masalah}

Berdasarkan uraian latar belakang maka rumusan masalah dari penelitian ini adalah bagaimana respon pertumbuhan tanaman jagung (Zea mays) dengan pemberian urea bersalut zeolit sebagai nitrogen lepas lambat?

\section{Fokus Penelitian}

Fokus penelitian ini adalah penelitian eksperimen dengan tujuan untuk mengetahui bagaimana respon pertumbuhan tanaman jagung (zea mays) dengan pemberian urea bersalut zeolit sebagai nitrogen lepas lambat.

\section{Metode Penelitian}

\section{Latar Belakang Umum Penelitian}

Penelitian ini dilaksanakan mulai April sampai Agustus 2017. Pembuatan pupuk dilakukan di Laboratorium Mikrobiologi Tanah Lantai III Timur Jurusan Biologi Universitas Negeri Makassar. Penanaman dan pemeliharaan jagung dilakukan di Rumah Kaca Ekofisiologi Balai Penelitian Tanaman Serelia (Balitsereal) Maros dan Analisis data nitrogen di Laboratorium Tanah Balai Pengkajian Teknologi Pertanian (BPTP) Kabupaten. Maros Sulawesi Selatan, 
(hlm. 152-162)

dengan menggunakan Rancangan Acak Kelompok (RAK) 3 pengelompokan dengan perlakuan Kontrol, Urea, Phosfat, Kalium (UPK), UPK Zeolit 10\%, UPK Zeolit 30\%, dan UPK Zeolit 50\%. Varietas jagung yang digunakan adalah HJ 21 Agritan.

\section{Subjek Penelitian}

Subjek penelitian ini adalah pertumbuhan tanaman meliputi lingkar batang, kadar klorofil daun, biomassa tanaman (akar, batang dan daun), berat tongkol, panjang tongkol, nitrogen daun dan nitrogen biji.

\section{Analisis data}

Pengolahan data dilakukan dengan menggunakan teknik analisis varian (Uji F) /ANOVA pada taraf kepercayaan $\alpha=0,05 \%$. Kemudian dilanjutkan dengan uji lanjut Duncan yang menggunakan program SPSS statistik 20.

\section{Hasil Penelitian}

Penelitian untuk melihat respon pertumbuhan tanaman jagung (Zea mays) terhadap pemberian urea bersalut zeolit sebagai nitrogen lepas lambat dengan parameter pengamatan meliputi lingkar batang, kadar klorofil daun, biomassa vegetatif tanaman akar, batang dan daun, berat tongkol, panjang tongkol, berat biji jagun, nitrogen daun dan nitrogen biji dapat dilihat dari hasil data yang terjsaji.

\section{Lingkar Batang Jagung (cm)}

Berdasarkan hasil analisis statistik menggunakan uji Anova data lingkar batang jagung terhadap perlakuan pemupukan urea dengan tambahan zeolit menunjukan hasil yang tidak berpengaruh, data rata-rata lingkar batang jagung tersaji pada Tabel 1.

Tabel 1. Rata-rata lingkar batang (cm) jagung pada umur 7 minggu setelah tanam (MST)

\begin{tabular}{|c|c|}
\hline Perlakuan & $\begin{array}{c}\text { Rata-rata } \\
\text { Lingkar Batang Jagung (Cm) }\end{array}$ \\
\hline Kontrol & $6,63^{\mathrm{a}}$ \\
Urea, Phosfat, Kalium & $6,70^{\mathrm{a}}$ \\
UPK Zeolit 10\% & $6,64^{\mathrm{a}}$ \\
UPK Zeolit 30\% & $6,84^{\mathrm{a}}$ \\
UPK Zeolit 50\% & $6,65^{\mathrm{a}}$ \\
\end{tabular}

Keterangan: Huruf yang sama menunujukan hasil yang tidak berpengaruh berdasarkan uji Anova

Rata-rata lingkar batang jagung paling tinggi terdapat pada perlakuan UPKZ 30\% sebesar $6.84 \mathrm{~cm}$ sedangkan rata-rata lingkar batang jagung paling rendah adalah Kontrol sebesar $6.63 \mathrm{~cm}$. 


\section{Kadar Klorofil Daun (\%)}

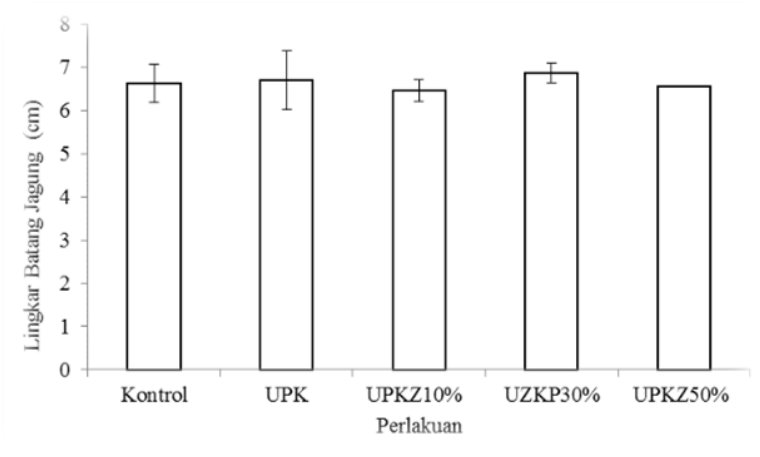

\section{Gambar 1. Rata-rata lingkar batang jagung (cm)}

Berdasarkan hasil analisis statistik menggunakan uji Anova data kadar klorofil daun terhadap perlakuan pemupukan urea dengan tambahan zeolit menunjukan hasil yang tidak berpengaruh, data kadar klorofil daun tersaji pada Tabel 2.

Tabel 2. Rata-rata kadar klorofil daun (\%) pada umur 8 minggu setelah tanam (MST)

\begin{tabular}{|c|c|}
\hline Perlakuan & Rata-rata \\
\hline Kontrol & Kadar Klorofil Daun (\%) \\
\hline Urea, Phosfat, Kalium & $37,63^{\mathrm{a}}$ \\
UPK Zeolit 10\% & $44,13^{\mathrm{a}}$ \\
UPK Zeolit 30\% & $44,13^{\mathrm{a}}$ \\
UPK Zeolit 50\% & $44,83^{\mathrm{a}}$ \\
& $45,75^{\mathrm{a}}$ \\
\hline
\end{tabular}

Keterangan : Huruf yang sama menunujukan hasil yang tidak berpengaruh berdasarkan uji Anova

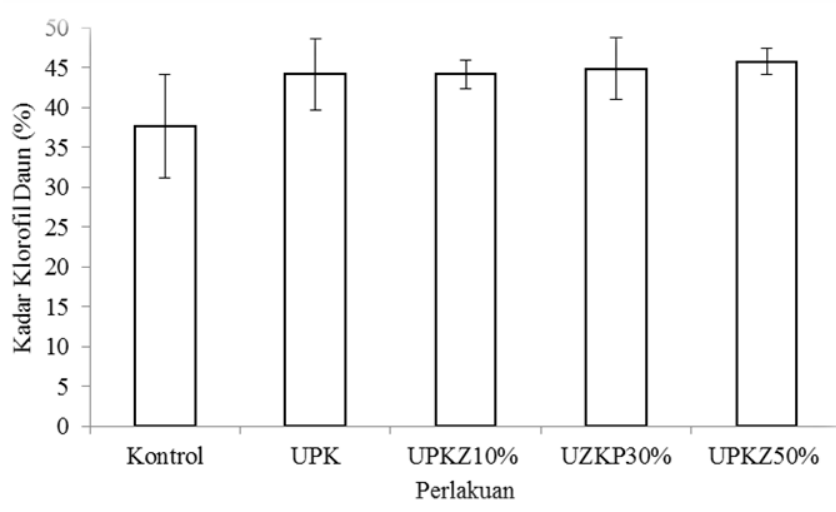

\section{Gambar 2. Rata-rata kadar klorofil daun (\%)}

Rata-rata kadar klorofil daun paling tinggi adalah perlakuan UPKZ 50\% sebesar 45,75\% dan rata-rata kadar klorofil daun yang paling rendah adalah Kontrol sebesar 37,63\%.

\section{Biomassa Tanaman Akar, Batang dan Daun (gram)}

Berdasarkan hasil analisis statistik menggunakan uji Anova data biomassa tanaman akar, batang dan daun terhadap perlakuan pemupukan urea dengan tambahan zeolit menunjukan hasil yang tidak berpengaruh, data rata-rata biomassa akar, batang dan daun tersaji pada Tabel 3. 
Tabel 3. Rata-rata biomassa tanaman (akar, batang dan daun) (gram) pada pasca panen

\begin{tabular}{|c|c|}
\hline Perlakuan & $\begin{array}{c}\text { Rata-rata } \\
\text { Biomassa Akar, Batang dan Daun } \\
\text { (gram) }\end{array}$ \\
\hline Kontrol & $169,00^{\mathrm{a}}$ \\
\hline Urea, Phosfat, Kalium & $185,33^{a}$ \\
\hline UPK Zeolit 10\% & $176,66^{\mathrm{a}}$ \\
\hline UPK Zeolit 30\% & $215,66^{a}$ \\
\hline UPK Zeolit 50\% & $197,00^{a}$ \\
\hline
\end{tabular}

Keterangan: Hurufyang sama menunujukan hasil yang tidak berpengaruh berdasarkan uji Anova

Rata-rata biomassa tanaman akar, batang dan daun paling tinggi adalah perlakuan UPK 30\% sebesar 215,66-gram dan rata-rata yang paling rendah adalah Kontrol sebesar 169 gram.

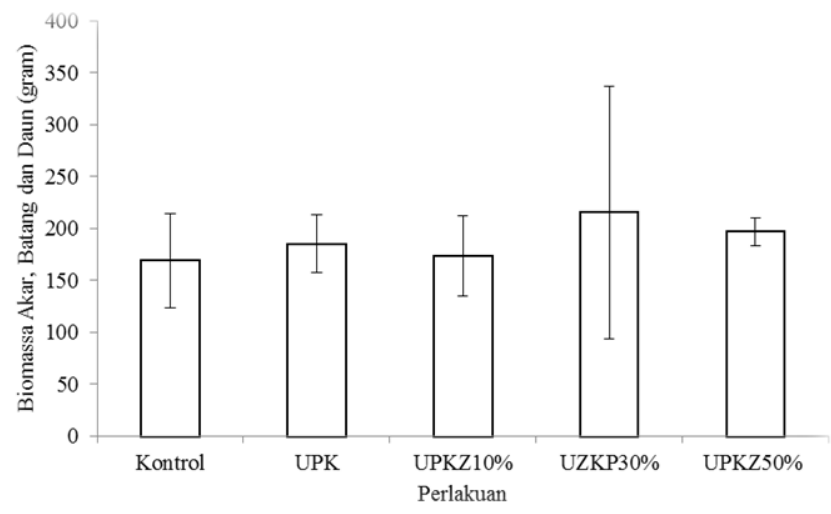

Gambar 3. Rata-rata biomassa tanaman akar, batang dan daun (gram)

\section{Berat Tongkol Jagung (gram)}

Berdasarkan hasil analisis statistik menggunakan uji Anova seperti yang tersaji pada lampiran II menunjukan berat tongkol jagung memiliki nilai signifikan lebih besar dari $\alpha=$ 0,05 kemudian dilanjutkan dengan hasil uji lanjut Duncan. Berat tongkol jagung seperti yang tersaji pada Tabel 4.

Tabel 4. Rata-rata berat tongkol jagung (gram) pada pasca panen

\begin{tabular}{|c|c|}
\hline & Rata-rata \\
Perlakuan & Berat Tongkol Jagung (gram) \\
\hline Kontrol & $55,83^{\mathrm{a}}$ \\
Urea, Phosfat, Kalium & $119,88^{\mathrm{b}}$ \\
UPK Zeolit 10\% & $120,92^{\mathrm{b}}$ \\
UPK Zeolit 30\% & $115,91^{\mathrm{b}}$ \\
UPK Zeolit 50\% & $119,65^{\mathrm{b}}$ \\
\hline
\end{tabular}

Keterangan: Huruf yang sama menunujukan hasil yang berbeda tidak nyata berdasarkan uji Duncan dengan taraf kepercayaan $\alpha 0,05$

Tabel 4. menunjukan berat tongkol jagung yang diperoleh berdasarkan hasil uji lanjut Duncan. Kontrol menunjukan hasil berbeda terhadap perlakuan UPK, UPKZ 10\%, UPKZ 30\% dan UPKZ 50\%, namun data berat tongkol perlakuan UPK tidak berbeda dengan perlakuan 
UPKZ 10\%, UPKZ 30\% dan UPKZ 50\%. Jadi berat tongkol jagung paling tinggi terdapat pada perlakuan UPKZ 10\%.

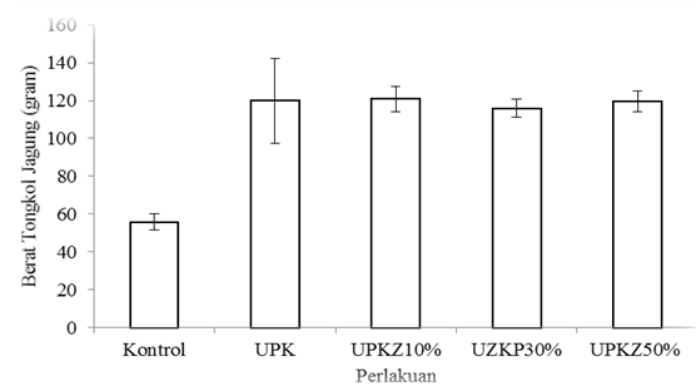

Gambar 4. Rata-rata berat tongkol jagung (gram)

\section{Panjang Tongkol Jagung (cm)}

Berdasarkan hasil analisis statistik menggunakan uji Anova seperti yang tersaji pada lampiran II menunjukan berat tongkol jagung memiliki nilai signifikan lebih besar dari $\alpha=$ 0,05 kemudian dilanjutkan dengan hasil uji lanjut Duncan. Panjang tongkol jagung seperti yang tersaji pada Tabel 5 .

\section{Tabel 5. Rata-rata panjang tongkol jagung $(\mathrm{cm})$ pada pasca panen}

\begin{tabular}{|c|c|}
\hline Perlakuan & $\begin{array}{c}\text { Rata-rata } \\
\text { Tongkol Jagung (cm) }\end{array}$ \\
\hline Kontrol & $10,05^{\mathrm{a}}$ \\
Urea, Phosfat, Kalium & $15,00^{\mathrm{b}}$ \\
UPK Zeolit 10\% & $14,25^{\mathrm{b}}$ \\
UPK Zeolit 30\% & $13,95^{\mathrm{b}}$ \\
UPK Zeolit 50\% & $14,87^{\mathrm{b}}$ \\
\hline
\end{tabular}

Keterangan: Huruf yang sama menunujukan hasil yang berbeda tidak nyata berdasarka uji Duncan dengan taraf kepercayaan $\alpha 0,05$

Tabel 5. menunjukan panjang tongkol jagung yang diperoleh berdasarkan hasil uji lanjut Duncan. Kontrol menunjukan hasil berbeda terhadap perlakuan UPK, UPKZ 10\%, UPKZ 30\% dan UPKZ 50\%, namun data panjang tongkol perlakuan UPK tidak berbeda dengan perlakuan UPKZ 10\%, UPKZ 30\% dan UPKZ 50\%. Jadi berat tongkol jagung paling tinggi terdapat pada perlakuan UPK.

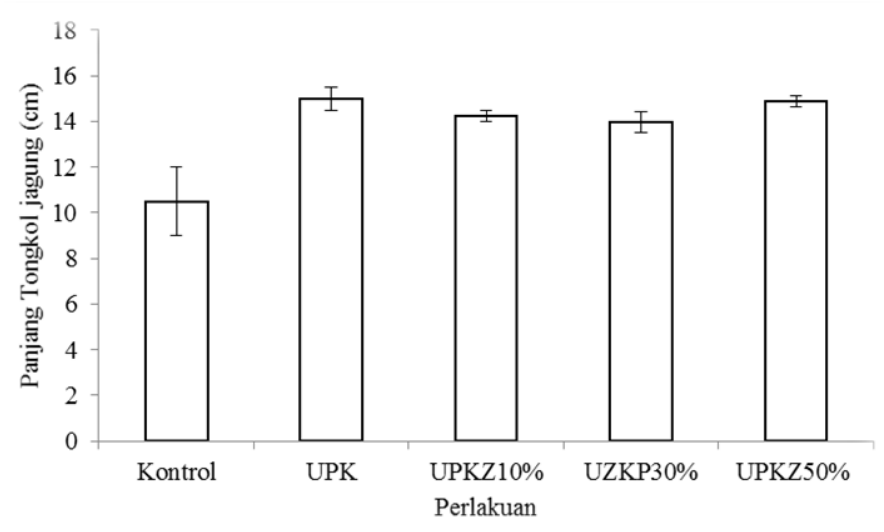

Gambar 5. Rata-rata panjang tongkol jagung (cm)

\section{Berat Biji Jagung (gram)}

Berdasarkan hasil analisis statistik menggunakan uji Anova seperti yang tersaji pada lampiran II menunjukan berat biji jagung memiliki nilai signifikan lebih besar dari $\alpha=0,05$ 
(hlm. 152-162)

kemudian dilanjutkan dengan hasil uji lanjut Duncan. Panjang tongkol jagung seperti yang tersaji pada Tabel 6.

Tabel 6. Rata-rata nitrogen daun jagung (\%) pada pasca panen

\begin{tabular}{|c|c|}
\hline Perlakuan & Rata-rata \\
Nitrogen Daun (\%)
\end{tabular}

Tabel 6. menunjukan panjang tongkol jagung yang diperoleh berdasarkan hasil uji lanjut Duncan. Kontrol dan UPKZ 30\% menunjukkan hasil berbeda terhadap semua perlakuan, namun data berat biji perlakuan UPKZ30\% tidak berbeda terhadap perlakuan UPK, UPKZ10\% dan UPKZ50\%. Data berat biji jagung yang paling tinggi adalah UPKZ50\%.

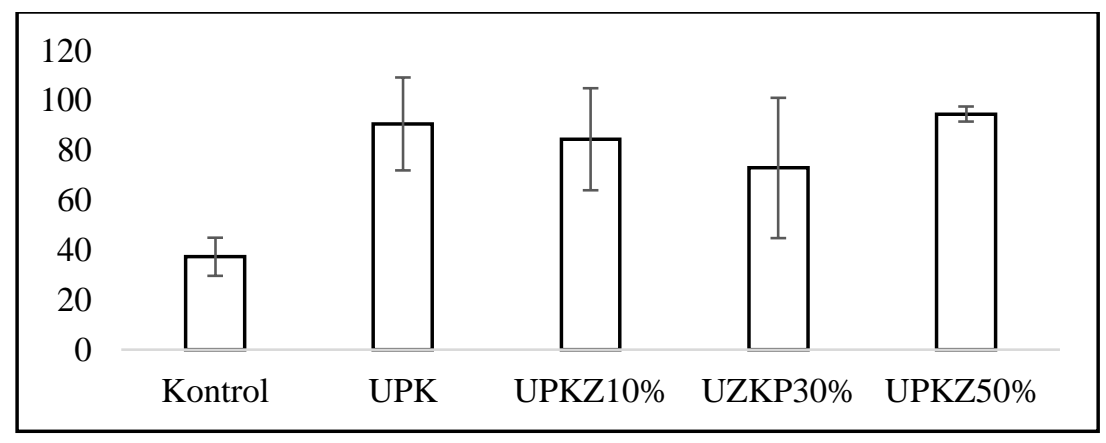

\section{Gambar 6. Rata-rata berat biji jagung (gram)}

\section{Nitrogen Daun Jagung (\%)}

Berdasarkan hasil analisis statistik menggunakan uji Anova rata-rata nitrogen daun jagung terhadap perlakuan urea dengan tambahan zeolit menunjukan hasil yang tidak berpengaruh, data rata-rata nitrogen daun jagung pada Tabel 6.

Tabel 6. Rata-rata nitrogen daun jagung (\%) pada pasca panen

\begin{tabular}{|c|c|}
\hline Perlakuan & $\begin{array}{c}\text { Rata-rata } \\
\text { Nitrogen Daun (\%) }\end{array}$ \\
\hline Kontrol & $2,03^{\mathrm{a}}$ \\
Urea, Phosfat, Kalium & $1,92^{\mathrm{a}}$ \\
UPK Zeolit $10 \%$ & $2,01^{\mathrm{a}}$ \\
UPK Zeolit $30 \%$ & $2,00^{\mathrm{a}}$ \\
UPK Zeolit 50\% & $1,93^{\mathrm{a}}$ \\
\hline
\end{tabular}

Keterangan: Hurufyang sama menunujukan hasil yang tidak berpengaruh berdasarkan uji Anova

Tabel 6. rata-rata nitrogen daun jagung paling tinggi adalah perlakuan UPKZ 10\% sebesar 2,01\% dan rata-rata nitrogen daun jagung yang paling rendah adalah perlakuan UPK. Sebesar $1,92 \%$. 


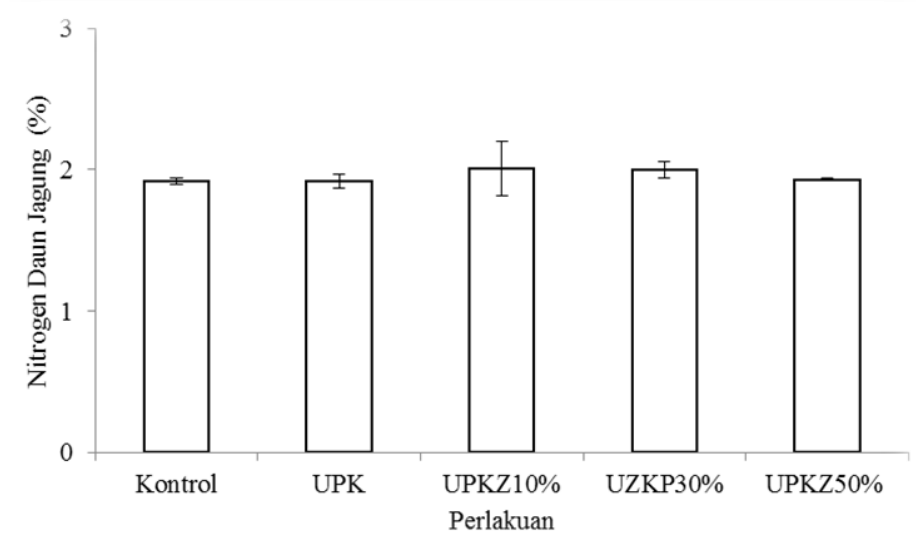

Gambar 7. Rata-rata nitrogen daun jagung (\%)

\section{Nitrogen Biji Jagung (\%)}

Berdasarkan hasil analisis statistik menggunakan uji Anova rata-rata nitrogen biji jagung terhadap perlakuan urea dengan tambahan zeolit menunjukan hasil yang tidak berpengaruh, data rata-rata nitrogen biji jagung tersaji pada Tabel 7.

Tabel 7. Rata-rata nitrogen biji jagung (\%) pada pasca panen

\begin{tabular}{|c|c|}
\hline Perlakuan & $\begin{array}{c}\text { Rata-rata } \\
\text { Nitrogen Biji (\%) }\end{array}$ \\
\hline Kontrol & 1,26 \\
Urea, Phosfat, Kalium & 1,26 \\
UPK Zeolit 10\% & 1,34 \\
UPK Zeolit 30\% & 1,33 \\
UPK Zeolit 50\% & 1,47 \\
\hline
\end{tabular}

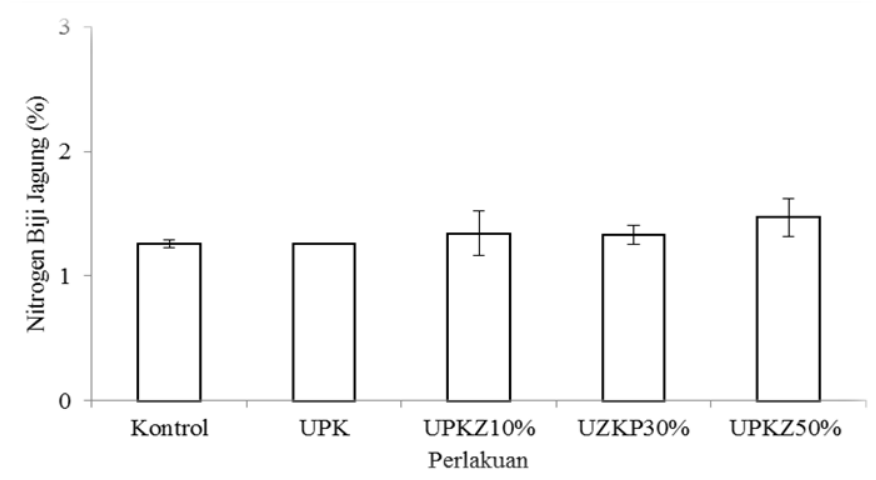

Gambar 8. Rata-Rata Nitrogen Biji Jagung (\%)

Keterangan: Huruf yang sama menunujukan hasil yang tidak berpengaruh berdasarkan uji Anova

Tabel 7. rata-rata nitrogen biji jagung. paling tinggi adalah perlakuan UPKZ 50\% sebesar $1.47 \%$ dan rata-rata nitrogen daun jagung yang paling rendah adalah Kontrol dan UPK sebesar $1.26 \%$.

\section{Pembahasan}

Pertumbuhan tanaman jagung (Zea mays) dengan pemberian urea bersalut zeolit dengan hasil penelitian menunjukkan respon terhadap berat tongkol dan panjang tongkol sedangkan 
Respon Pertumbuhan Jagung (Zea mays) dengan Pemberian Urea Bersalut

Zeolit Sebagai Nitrogen Lepas Lambat

(hlm. 152-162)

untuk lingkar batang jagung, kadar klorofil daun, biomassa tanaman (akar, batang dan daun), nitrogen daun dan nitrogen biji menunjukan hasil yang tidak berpengaruh.

Pada berat tongkol jagung dari hasil uji lanjut menunjukan hasil yang berbeda terhadap perlakuan lainnya. Hal ini menunjukan bahwa aplikasi urea bersalut zeolit memberikan hasil yang paling tinggi sedangkan yang tidak diberi perlakuan yang paling rendah. Hal ini diduga pembentukan tongkol pada fase generatif membutuhkan unsur hara sehingga pemberian aplikasi pupuk urea zeolit dengan konsetrasi $10 \%$ lebih baik dibanding tanpa pemberian aplikasi (Kontrol). Menurut Wu and Lin (2000) Pengaruh penggunaan Nitrogen (N) terhadap kualitas dan kuantitas hasil adalah penyempurnaan proses pengisian biji secara penuh sehingga dapat mengeraskan dan mencegah pengecilan biji pada ujung tongkol, hal ini berkorelasi positif dengan berat tongkol pada tanaman jagung.

Pada panjang tongkol dari hasil uji lanjut menunjukan hasil yang berbeda terhadap perlakuan lainnya. Hasil panjang tongkol yang paling tinggi ditunjukan pada perlakuan urea bersalut zeolit dengan konsentrasi $10 \%$ yang paling rendah yang tidak diberi perlakuan. Hal ini diduga Kontrol tidak memiliki hara yang banyak dalam tanah. Menurut Arief, et al., (2013) Kandungan Nitrogen $(\mathrm{N})$ berpengaruh pada proses fotosintesis, karena itu unsur $\mathrm{N}$ yang dapat diserap oleh tanaman sangatlah mempengaruhi panjang tongkol/tanaman yang dihasilkan.

Pada lingkar batang jagung tidak berpengaruh. Hal ini diduga karena unsur hara nitrogen tersedia dalam tanah dengan jumlah yang optimal dan seimbang sehingga mampu memberikan keseimbangan hara bagi tanaman yang menyebabkan pemberian pupuk urea bersalut zeolit tidak berpengaruh terhadap perlakuan. Namun, pada lingkar batang ini perlakuan paling tinggi terdapat pada perlakuan UPK Zeolit 30\% dan paling rendah adalah Kontrol. Menurut Syarifuddin et, al., (2012) bahwa untuk dapat tumbuh dengan baik tanaman membutuhkan hara $\mathrm{N}$, P dan $\mathrm{K}$ yang merupakan unsur hara yang esensial dimana unsur hara ini berperan dalam pertumbuhan tanaman secara umum pada fase vegetatif, dimana lingkar batang diambil pada fase vegetatif. Heard (2004), menambahkan bahwa pemberian pupuk pada tanaman yang memasuki masa vegetatif akan meningkatkan pertumbuhan dan pertambahan jumlah sel, serapan hara termasuk nitrogen yang merupakan salah satu komponen sel dan pembentukan makromolekul, sehingga dapat meningkatkan kualitas batang yang lebih kuat agar mengurangi resistensi terhadap kerebahan.

Pemberian zeolit pada tanah yang mempunyai Kapasitas Tukar Kation (KTK) rendah sehingga dapat meningkatkan KTK tanah. Menurut Polat et al., (2004) Zeolit yang diberikan pada tanah, karena zeolit mempunyai kapasitas penyerapan hara terutama Kalium (K) dan Amonium $\left(\mathrm{NH}_{4}\right)$ yang tinggi, maka kemampuan tanah dalam mengikat unsur-unsur tersebut dapat meningkat. Pengurangan kehilangan nitrogen baik karena pencucian ataupun nitrifikasi dapat meningkatkan hasil produksi tanaman. Peningkatan produksi akibat pemberian zeolit disebabkan adanya peningkatan efisiensi nitrogen khususnya mengurangi pencucian nitrat. Penggunaan zeolit 3 dan 6 ton/ha menghasilkan akumulasi nitrogen yang lebih tinggi dibandingkan dengan kontrol yang diperlakukan dengan pupuk $\mathrm{N}$ dua kali lipat. Zeolit dapat menghambat konversi $\mathrm{NH}_{4}$ menjadi nitrat sampai 30-40\% (Suwardi, 2009).

Karakteristik zeolit adalah struktur kristal tiga dimensi yang memiliki kemampuan untuk menghidrasi dan mengeringkan secara reversibel dan menukar beberapa kation konstituennya. Bila pupuk urea ditambahkan bersama dengan zeolit ke tanah tanaman, Amonium $\left(\mathrm{NH}_{4}+\right)$ akan terjebak sementara di pori zeolit dan kemudian dilepaskan secara perlahan untuk diambil oleh akar tanaman. Oleh karena itu, zeolit memainkan peran untuk menahan kation $\left(\mathrm{NH}_{4}+\right)$, menghasilkan peningkatan efisiensi kation yang meningkat. $\mathrm{NH}_{4}+$. Dilaporkan bahwa pupuk urea di dalam tanah dapat ditekan dengan membuat pupuk slow release fertilizer (SRF) yang dibuat dari campuran urea dan zeolit dengan perbandingan $70 \%$ urea : zeolit 30\%, agar pupuk urea dapat disimpan sampai dengan 30\%, zeolit stabil dan kecenderungan efek residu di tanah relatif lebih tinggi (Al-Jabri, 2010).

Pada kadar klorofil daun pada semua jenis perlakuan nampak tidak begitu jauh berbeda, namun hanya pada Kontrol yang tidak berpengaruh nyata. Hal ini diduga yang tidak diberi perlakuan pemberian pupuk kekurangan nitrogen yang menyebabkan kadar nitrogen daunnya 
berkurang. Menurut Demanik, et al,. (2011) bahwa pupuk urea sama-sama menyumbangkan nitrogen bagi tanaman. Nitrogen berperan sebagai penyusun klorofil yang menyebabkan daun berwarna hijau. Hal ini dapat dilihat pada saat diamati, dimana warna daun yang diberi pelakuan pupuk urea bersalut zeolit dengan konsentrasi 30\% tampak lebih hijau.

Fontosintesis yang baik ditentukan oleh kadar klorofil, dimana kadar klorofil daun ditentukan oleh nitrogen. Nitrogen adalah komponen utama penyusun klorofil (Islam et al., 2010). Kadar N daun lebih tinggi dari kadar N biji menunjukkan tidak ada remobilisasi N ke biji menyebabkan daun tetap berwarna hijau hingga masa panen. Hal ini menyebabkan proses fotosintesis berjalan lebih lama. Fotosintesis yang lama dapat membantu tanaman terus mengisi biji (Dawson et al., 2008).

Pada biomassa tanaman (akar, batang dan daun) diukur pada pasca panen. Biomassa tanaman akar, batang dan daun terhadap perlakuan pemupukan urea dengan tambahan zeolit menunjukan hasil yang tidak berpengaruh. Hasil biomassa tanaman akar, batang dan daun pada semua jenis perlakuan nampak tidak begitu jauh berbeda, namun hanya pada Kontrol yang tidak berpengaruh. Hal ini diduga karena jumlah nutrisi dan nitrogen didalam tanah sangat berbeda-beda. Kontrol tidak diberikan perlakuan penambahan pupuk sehingga menyebabkan jumlah nitrogen didalam tanah sangat kurang. Menurut Marsono dan Sigit, (2011) Nitrogen (N) adalah unsur hara yang sangat penting dalam pertumbuhan tanaman. Kandungan $\mathrm{N}$ total berkisar antara $45-46 \%$ kandungan $\mathrm{N}$ yang tinggi sangat dibutuhkan pada pertumbuhan awal tanaman jagung.

Pada nitrogen daun dan nitrogen biji diukur pasca panen. Kadar nitrogen menujukan hasil yang tidak berpengaruh. Pada nitrogen daun Kontrol paling tinggi dan pada nitrogen biji perlakuan urea bersalut zeolit 50\% yang paling tinggi. Hal ini diduga kadar nitrogen $(\mathrm{N})$ daun lebih tinggi dari kadar $\mathrm{N}$ biji menunjukkan tidak ada remobilisasi $\mathrm{N}$ ke biji menyebabkan daun tetap berwarna hijau hingga masa panen.

Unsur hara nitrogen didalam daun dibutuhkan dalam jumlah yang banyak, namun nitrogen juga berperan dalam translokasi karbohidrat dari daun ke organ tanaman lain. Nitrogen berperan dalam perombakan karbohidrat menjadi protein sehingga mampu mempercepat proses translokasi karbohidrat, sehingga pada kondisi demikian tidak terjadi penimbunan karbohidrat didalam daun. Tanaman biji khususnya, pada tanaman jagung memerlukan pasokan nitrogen yang relatif tinggi untuk biji. Bila pasokan untuk nitrogen menurun selama fase tersebut maka tanaman akan memindahkan nitrogen dari daun ke biji, dan mempercepat penuaan daun.

Hal ini menyebabkan proses fotosintesis berjalan lebih lama. Fotosintesis yang lama dapat membantu tanaman terus mengisi biji (Dawson et al., 2008). Selain kadar N yang tinggi di daun, fotosintesis juga dipengaruhi oleh sifat stay green dari varietas jagung Varietas jagung yang digunakan pada penelitian ini adalah HJ21 Agritan (Balitsereal, 2014). Tanaman stay-green menunda penuaan daun saat pengisian biji yang dapat meningkatkan hasil yang lebih tinggi tetapi menurunkan efisiensi remobilisasi $\mathrm{N}$ dan menurunkan kadar klorofil protein biji (Daubresse et al., 2010). Penuaan daun yang dimaksud adalah perubahan warna daun menjadi kuning akibat kadar $\mathrm{N}$ klorofil berkurang. Penuaan dini pada daun terjadi karena remobilisasi dari $\mathrm{N}$ vegetatif melalui degradasi protein dan asam amino daun (Daubresse et al., 2010). Menurut Feller et al., (2008) bahwa akhinya, persentase akumulasi $\mathrm{N}$ tertinggi itu terjadi di biji. Hal ini berlaku jika terjadi reemobilisasi $\mathrm{N}$. Jadi jika terjadi remobilisasi $\mathrm{N}$ dari daun maka $\mathrm{N}$ daun akan rendah dan $\mathrm{N}$ biji akan tinggi.

\section{Kesimpulan}

Berdasarkan hasil penelitian yang telah dilakukan yakni respon pertumbuhan jagung (Zea mays) dengan pemberian urea bersalut zeolit seabagai nitrogen lepas lambat, dapat disimpulkan bahwa pada berat tongkol dan panjang tongkol menunjukan hasil yang berbeda terhadap perlakuan lainnya dengan menggunakan aplikasi urea bersalut zeolit dengan 
konsentrasi 10\%. Sedangkan untuk lingkar batang, kadar klorofil daun, biomassa tanaman (akar, batang dan daun), nitrogen daun dan niitrogen biji menunjukkan hasil yang tidak berpengaruh namun jika dilihat hasil rata-rata aplikasi urea bersalut zeolit dengan konsentrasi $30 \%$ paling tinggi.

\section{Referensi}

Arif, W, Thamrin, H, Soekarmtono, S. (2013). Pengaruh Pengaplikasian Zeolit dan Pupuk Urea pada Pertumbuhan dan Hasil Tanaman Jagung Manis (Zea mays). Jurusan Budidaya Pertanian Fakultas Pertanian, Universitas Brawijaya Malang Jl. Veteran, Malang 65145, Jawa Timur, Indonesia.

Balitsereal. (2014). HJ 21 dan HJ 22 AGRITAN, Duo VUB Jagung Hibrida dengan Berbagai Kelebihan. Balai Penelitian dan Pengembangan Tanaman Pangan. Maros. diakses tanggal 14 Januari 2018 http://pangan.litbang.pertanian.go.id/ berita-490-hj-21-dan-hj22-agritan-duo-vub-jagung-hibrida-dengan-berbagai-kelebihan.html

Feller, U., Anders, I., \& Demirevska, K. (2008). Degradation of Rubisco and Other Chloroplast Proteins Under Abiotic Stress. Gen Appl Plant Physiol, 34, 5-18.

Heard, J. (2004). Nutrient Uptake and Removal Patterns In High Yielding Manitoba Corn Manitoba Agriculture. (http://www.maize.corncob.html)

Polat, E., Karaca, M., Demir, H., \& Onus, A. N. (2004). Use of Natural Zeolite (Clinoptilolite) In Agriculture. Journal of Fruit and Ornamental Plant Research, 12 (1), 183-189.

Syafruddin, S., Nurhayati, N., \& Wati, R. (2012). Pengaruh Jenis Pupuk Terhadap Pertumbuhan dan Hasil Beberapa Varietas Jagung Manis. Jurnal Floratek, 7 (1), 107-114.

Suwardi \& Efendi, R. (2009). Efisiensi Penggunaan Pupuk N Pada Jagung Komposit Menggunakan Bagan Warna Daun. Balai Penelitian Tanaman Serealia. Disampaikan pada Prosiding Seminar Nasional Serealia.

\begin{tabular}{|c|c|}
\hline Nur Aina & $\begin{array}{l}\text { S,Si, Fakultas Matematika dan Ilmu Pengetahuan Alam, } \\
\text { Universitas Negeri Makassar, Makassar } \\
\text { E-mail: ajhyaynha52@gmail.com }\end{array}$ \\
\hline Oslan Jumadi & $\begin{array}{l}\text { Professor., M.Si., M.Phil., Ph. D, Lecture, Fakultas Matematika } \\
\text { dan Ilmu Pengetahuan Alam, Universitas Negeri Makassar, } \\
\text { Makassar. } \\
\text { E-mail: oslanj@gmail.com }\end{array}$ \\
\hline St. Fatmah Hiola & $\begin{array}{l}\text { Dr, S. P., M. Si., Lecture, Fakultas Matematika dan Ilmu } \\
\text { Pengetahuan Alam, Universitas Negeri Makassar, Makassar. } \\
\text { E-mail: auhiola@gmail.com }\end{array}$ \\
\hline
\end{tabular}

